\title{
EXPERIMENTAL TOOLING FOR CONTACT STRESS MEASUREMENT IN BULK METAL FORMING PROCESSES
}

\author{
Dragiša Vilotić, Miroslav Plančak \\ University of Novi Sad, Faculty of technical science, Serbia
}

\begin{abstract}
Knowledge of contact stresses in metal forming operations is essential not only for optimal die design, but also for theoretical and numerical analysis of the metal forming processes. Determination of contact stresses can be performed theoretically and experimentally. This paper presents a tool construction with built-in pin-load cells for experimental determination of contact stresses and friction coefficient at upsetting of prismatic specimen with cylindrical dies. This construction allows measurement of contact stresses in any point of the contact surface of specimen, due to adjustable location of pin-load cells. The adjustments are performed by turning cylindrical dies around its own axis in combination with the change of axial position of the specimen. Experimental determination of contact stresses in upsetting of Ck35 prismatic specimens using cylindrical tools was performed at the Laboratory for technology of plasticity, FTN Novi Sad.
\end{abstract}

Key words: Contact stresses, Cylindrical dies, Pin-load cell

\section{INTRODUCTION}

Metal forming technologies are extensively used in the production of semi-finished products (rolled metal sheets, wire, various profiles, etc.), as well as in the production of finished parts which are ready for use in various products with minor finishing (Near Net Shape Forming) or with no finishing at all (Net Shape Forming). Modern plastic forming technology is used in automotive industry, aviation industry and industries producing other types of transportation vehicles. It also has applications in processing and agricultural industries, electrical industry, energy industry, nuclear and aerospace industries, etc. More than $80 \%$ of all metal products undergo some kind of forming. Optimization of plastic forming demands extensive knowledge of all relevant process parameters in order to reduce the number of deformation stages to a minimum,

*Corresponding author's email: vilotic@uns.ac.rs 
thus allowing minimal costs of production. The determination of relevant process parameters, prediction of material destruction during forming and optimal process planning are based on analysis of stresses and strains throughout all deformation stages.

Numerous methods, which are used in metal forming for the determination of forces, stresses and strains, can be generally classified into theoretical and experimental methods.

Analytical methods to obtain contact stresses are based on advanced theory of plasticity [1], [2],[3],[4],[5]. An example of experimental method for determination of force in backward extrusion is presented in [6]. Analytical methods require a number of assumptions and simplifications (especially in analyzing of complex workpiece shapes). Therefore, this paper presents a method of experimental determination of contact stresses in upsetting of prismatic specimens by cylindrical tools, using pin-load cells.

\section{DESIGN OF CYLINDRICAL TOLLS WITH PIN LOAD CELL}

Cylindrical dies for compression of prismatic workpiece, mounted on the Sack\&Kieselbach hydraulic press with 6,3 MN nominal force, are shown in Figure 1.

Figure 2 shows cylindrical dies with built-in pin-load cells for the determination of contact normal and tangential stress. Cylindrical dies (Figure 2) with a $100 \mathrm{~mm}$ diameter are made from steel $100 \mathrm{Cr} 6$ and hardened to $60 \mathrm{HRC}$. In Figure 3 specimen from Ck35 material after deformation is shown. The $\varnothing 2 \mathrm{~mm}$ pin-load cell (Figure 4) is made from HS6-5-2 high-speed steel and also hardened to $60 \mathrm{HRC}$, while the measuring cylinder $\varnothing 10 / 7 \mathrm{~mm}$ is made from C45 (in normalized state); ball diameter is $\varnothing 4,7 \mathrm{~mm}$. The clearance between the pin-load cell and the die hole is 0,02 $\mathrm{mm}$. Attached to the cylindrical measuring element (dynamometer, position 2, Figure 5) are four strain gauges ("Hottinger" 1,5/120 LY21). Pin-load cells are located relative to workpiece by rotating cylindrical dies, i.e. by changing the angle $\alpha$ (Figure 5).

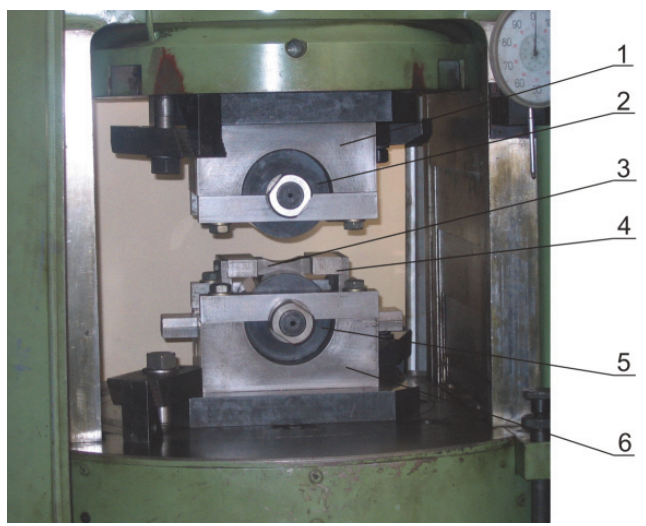

Figure 1 - Cylindrical dies at hydraulic press Sack\&Kieselbach 6,3MN:

1,6 - die housing, 2,5 - cylindrical dies, 3 - specimen, 4 - specimen positioner

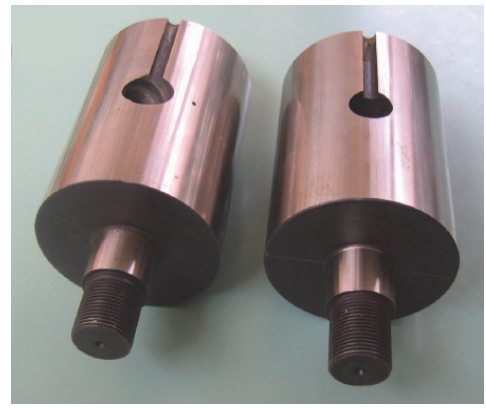

Figure 2 - Cylindrical dies for prismatic workpiece compression $\varnothing 100 \mathrm{~mm}$

The measuring unit (Figure 5) used for the measurement of normal stress $\sigma_{\mathrm{n}}$ is built in the upper cylinder along its radius, while the measuring element with the angle of $30^{\circ}$ with respect to the 
radial direction is built in the lower cylinder and is used for the determination of the tangential contact stress $\tau_{\mathrm{k}}$.

Over the measuring pin (position 4, Figure 5), and the ball (7), contact load is transferred on the measuring cylinder (2) which has four strain gauges attached, forming a Wheatstone bridge. Under that load, the measuring cylinder and strain gauges undergo elastic deformation which causes fluctuation of electrical resistance and generates electrical signal, which is first amplified and then registered in computer as a value analogous to the pin load.

One of the essential issues with the pin load cell method is the establishment of relationship between the electronic signal from the measuring cylinder (dynamometer) and the pin load, i.e. the issue of system calibration. In this case, the calibration of the measuring cylinder (component 2 , Figure 5) is performed by loading the cylinder with a known force on a precise press while recording the electrical signal from the measuring system.

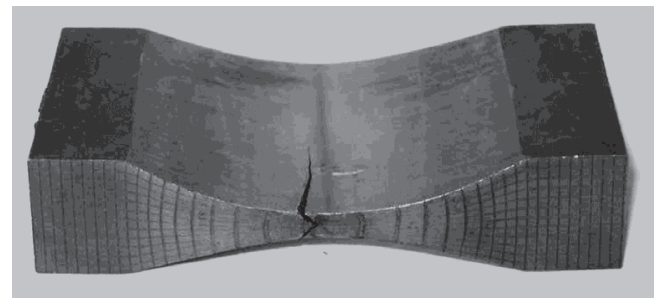

Figure 3 - Specimen after deformation (S-300)

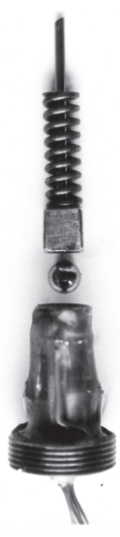

Figure 4 - Measuring pin load cell

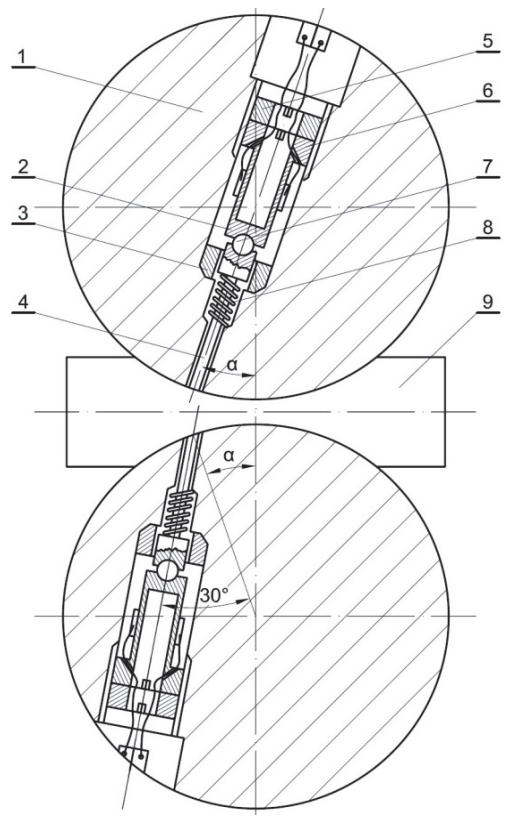

Figure 5 - Pin load cell in cylindrical dies: 1 - cylindrical die, 2 - measuring cylinder, 3 - safety ring, 4 - pin, 5 - safety nut, 6 - strain gauge, 7 - ball, 8 - spring, 9 - specimen 


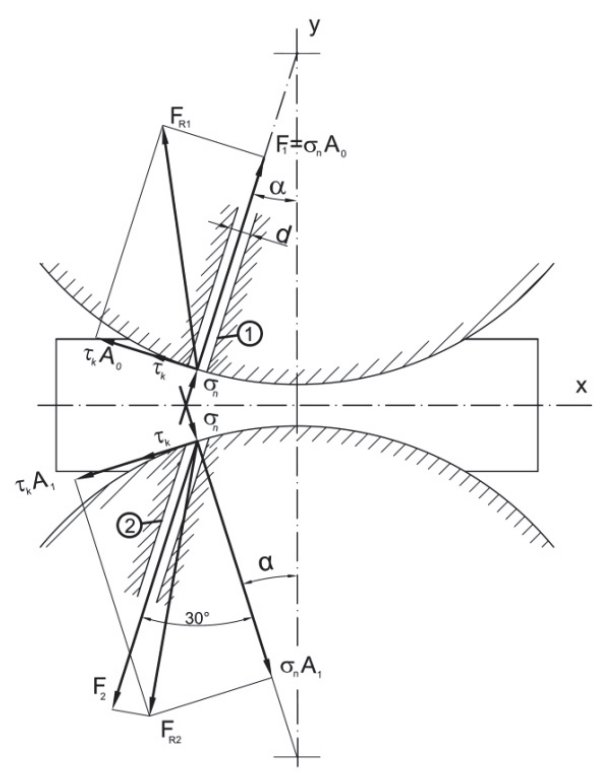

Figure 6 - Analysis of loading on measuring pins

The relationship between contact stresses and forces on measuring pins - case without friction in pin housing - can be established based on the load scheme, Figure 6:

$$
\begin{aligned}
\sigma_{n} & =\frac{F_{1}}{A_{0}} \\
\tau_{k} & =\sqrt{3}\left(\frac{F_{2}}{A_{0}}-\sigma_{n}\right) \\
\mu & =\frac{\tau_{k}}{\sigma_{n}}
\end{aligned}
$$

where:

$F_{1}, F_{2}$ are the loads measured by pin 1 and 2, Figure 5.

$\mathrm{A}_{0}$ is the area of pin cross section

On the basis of the distribution of the contact stresses it is possible to determine the deformation force:

$$
F=\int_{A} \sigma_{n} \cdot(\cos \alpha+\mu \cdot \sin \alpha) \cdot d A
$$

Using the die shown in Figure 1 experimental determination of the contact stresses in upsetting of prismatic specimen by cylindrical dies was carried out in Laboratory for technology of plasticity 
on Faculty of technical sciences - Novi Sad. The investigation was performed with specimens series SP - 300 (initial dimensions: 48x40x18mm, made of steel Ck35 i.e. EN 1C35). Some of results are presented in Figures 7, 8 and 9.

Figure 7 shows the load measured by the upper pin (Figure 5) for different strokes. The curves are marked according to the position of the measured point on the workpiece. Based on these values the contact stress $\sigma_{\mathrm{n}}$ was obtained. Figure 8 shows a 3-dimensional contact stress distribution for the stroke of $\mathrm{S}=8 \mathrm{~mm}$.

a)

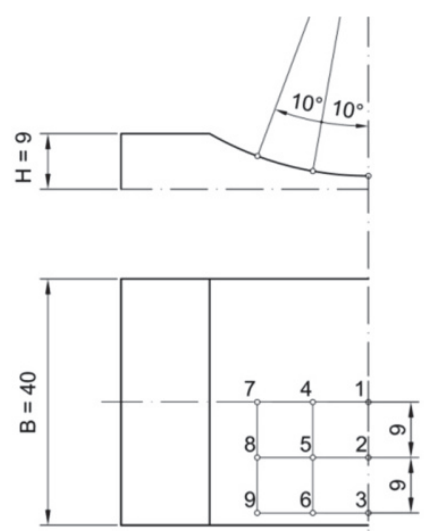

b)

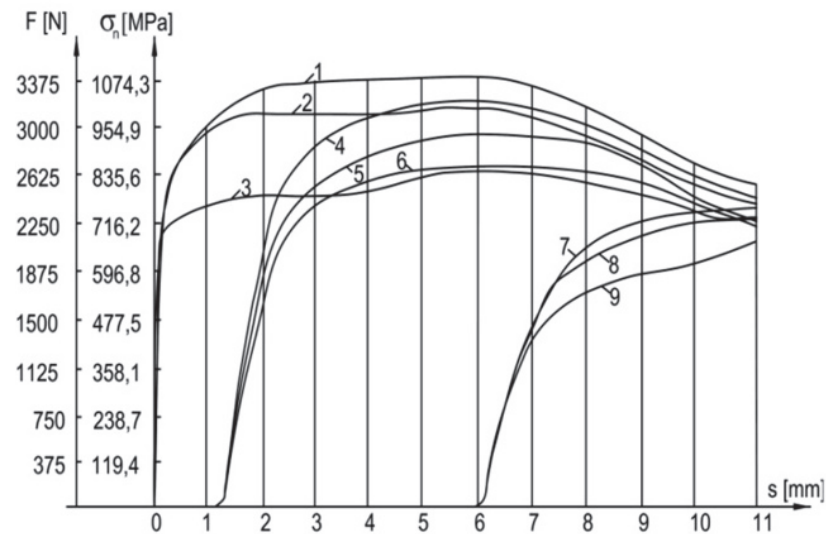

Figure 7 - Load at measuring pin in different points of specimen (SP-300)

a) position of measuring points,

a) load-stroke diagram

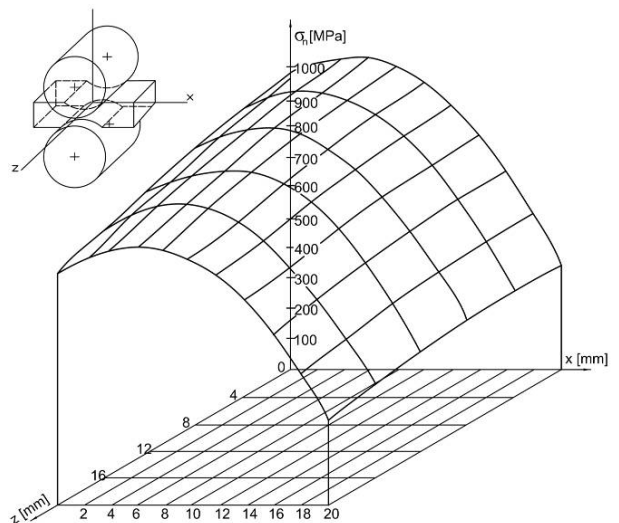

Figure 8 - Normal contact stress distribution at $S=8 \mathrm{~mm}(S P-300)$

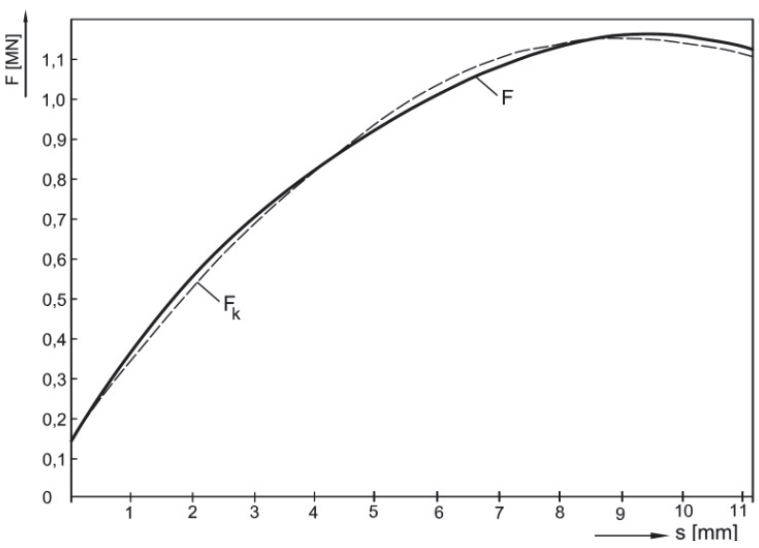

Figure 9 - Forming load diagram

Based on the measured normal contact stress, using expression (7), the total deformation load was calculated as shown on the diagram in Figure 9. The same diagram shows the change of the 
deformation load which was determined experimentally, by direct measurement on the machine for the specimens from SP - 300 series. The deformation load results show almost perfect overlapping which indicates high precision and reliability of the pin-load cell method.

Tangential contact stress and friction coefficient were determined for $\mathrm{Ck} 35$ prismatic specimens of

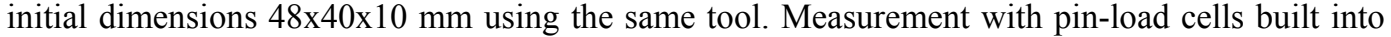
the upper and lower die was performed at 9 locations according to the layout given in Figure 10. Distribution of normal and tangential stress for $\mathrm{S}=4 \mathrm{~mm}$ die stroke, are shown in Figure 11. Based on this data, the coefficient of contact friction was calculated (Table 1) leading to the conclusion that this coefficient varies along coordinate axes $(\mathrm{X}, \mathrm{Z})$. Thus, the usual assumption of constant friction coefficient does not hold true in this case.

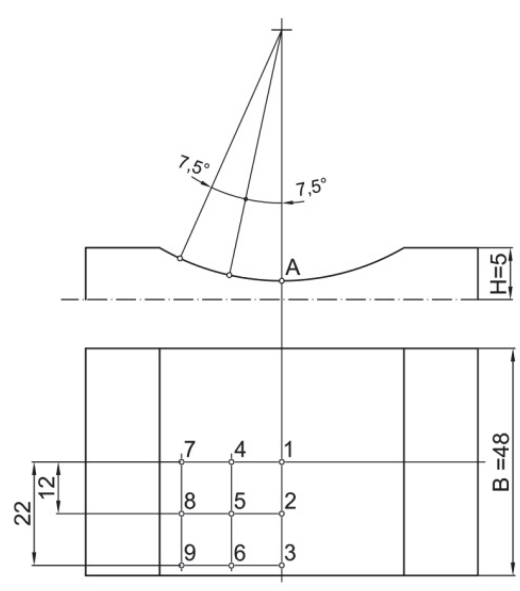

Figure 10 - Layout of measurement points

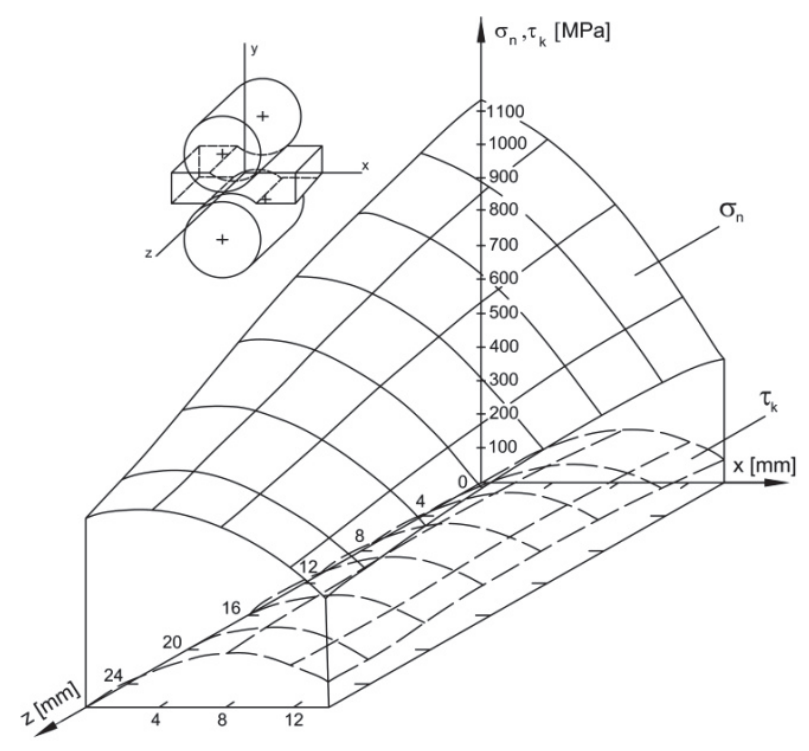

Figure 11 - Distribution of contact stresses

Table 1: Tangential contact stress and friction coefficient

\begin{tabular}{|c|c|c|c|c|c|c|c|}
\hline & & \multicolumn{3}{|c|}{$\mathrm{S}=2 \mathrm{~mm}$} & \multicolumn{3}{|c|}{$\mathrm{S}=4 \mathrm{~mm}$} \\
\hline $\begin{array}{c}\mathrm{Z} \downarrow \\
{[\mathrm{mm}]}\end{array}$ & $\mathrm{X} \rightarrow[\mathrm{mm}]$ & 0 & 6,53 & 12,04 & 0 & 6,53 & 12,04 \\
\hline \multirow{2}{*}{0} & $\tau_{k}[\mathrm{Mpa}]$ & 0 & 125,8 & - & 0 & 96,9 & 146,3 \\
\cline { 2 - 8 } & $\mu$ & 0 & 0,160 & - & 0 & 0,103 & 0,312 \\
\hline \multirow{2}{*}{12} & $\tau_{k}[\mathrm{Mpa}]$ & 0 & 202,1 & - & 0 & 200,8 & 109,0 \\
\cline { 2 - 8 } & $\mu$ & 0 & 0,297 & - & 0 & 0,255 & 0,229 \\
\hline \multirow{2}{*}{22} & $\tau_{k}[\mathrm{Mpa}]$ & 0 & 130,9 & - & 0 & 176,5 & 124,3 \\
\cline { 2 - 8 } & $\mu$ & 0 & 0,250 & - & 0 & 0,302 & 0,287 \\
\hline
\end{tabular}




\section{CONCLUSION}

The determination of relevant process parameters, prediction of material formability and optimal process planning are based on analysis of stresses and strains throughout all deformation stages. Numerous methods, which are used in plastic forming for the determination of stresses and strains, can be generally classified into theoretical, experimental and numerical.

The subject of this paper is the pin-load cell method of contact stress determination and its application on the process of prismatic cylinder upsetting by cylindrical dies. The tool, with pinload cells built into both upper and lower die, is constructed in a way which allows measurement of normal and tangential contact stresses and friction coefficient at any point on the workpiece contact surface. High agreement between the deformation load diagram (derived by the integration of contact stresses) and the diagram derived by measurement on the hydraulic press, indicate that the pin-load cell method yields precise and reliable results in the case of contact stresses.

The results for contact stresses in bulk forming, derived using pin-load cells, had been used to check the state of materials being formed, i.e. to check material deformability[7],[8],[9] as well as local stresses in tools. The reviewed method for measurement of contact stresses can also be used with other methods of cold and warm bulk and sheet forming, provided that the mounting of pinload cells onto the tool components is possible.

\section{ACKNOWLEDGEMENT}

This paper is a part of the investigation within the project EUREKA E!5005. Authors are very grateful for the financial support.

\section{REFERENCES}

[1] Johnson W., Mellor P.B.: Plasticity for Mechanical Engineers, Van Nostrand Reinhold Company, London, 1980.

[2] Kolmogotov V. L.: Mechnanics of technology of plasticity (in Russian), UPI, Ekateromburg, 2001.

[3] Avitzur B.: Metal forming: Processes and Analysis, McGraw-Hill, New York, 1968.

[4] Tomljenov A. D.: Theory of plasticity (in Russian), Masinostroenie, Moskva 1972.

[5] Tarnovskij I. Ja: Theory for technology of Plasticity - Variational methods for determination of forming load and deformation (in Russian), GNTI, Moskva, 1963.

[6] Bašić $\mathrm{H}$ : The measurement of deformation force variation by using strain gages in extrusion technology, Journal for Technology of Plasticity, Vol. 29, Nr 1-2, 2004, pp 25-23.

[7] Vilotić D., Plančak M., Grbić S., Alexandrov S., Chikanova N.: An Approach to Determining the Workability Diagram Based on Upsetting Tests, Fatigue and Fracture of Engineering Materials and Structures, Vol.1, No 26, 2003, pp 305-310.

[8] Vilotić D., Shabaik A.: Analysis of Upsetting with Profiling Dies, Transaction of the ASME Journal of Engineering Materials and Technology, Vol. 107, 1985, pp 261-264.

[9] Aleksandrov S., Vilotic D., Goldstein R., Chikanova N.: The Determination of the Workablity Diagram, Journal of Mechanics of Solids, Allerton Press, Inc., Vol. 34, No. 4, 1999, pp 118125.

Journal for Technology of Plasticity, Vol. 36 (2011), Number 1 


\title{
ALATI ZA EKSPERIMENTALNO ODREĐIVANJE KONTAKTNIH NAPONA U PROCESIMA ZAPREMINSKOG PLASTIČNOG DEFORMISANJA
}

\author{
Dragiša Vilotić, Miroslav Plančak \\ Univerzitet u Novom Sadu, Fakultet tehničkih nauka, Srbija
}

\begin{abstract}
REZIME
Određivanje relevantnih parametara procesa po fazama obrade plastičnim deformisanjem bazirano je na detaljnoj analizi napona i deformacija. Metode određivanja napona i deformacija dele se na teorijske, eksperimentalne i numeričke.

U ovom radu prikazana je metoda eksperimentalnog određivanja kontaktnih napona pomoću merne čivije u procesu sabijanja prizmatičnog pripremka cilindričnim alatima. U radu je prikazana detaljna konstrukcija alata sa ugrađenim mernim čivijama za određivanje kontaktnih napona i koeficijenta trenja pri sabijanju cilindričnim alatima. Ovakva izvedba alata omogućuje merenje kontaktnih napona u bilo kojoj tački kontaktne površine, zbog mogućnosti promene početnog položaja merne čivije rotiranjem cilindričnih pritiskivača u kombinaciji sa aksijalnom promenom položaja pripremka. Eksperimentalna ispitivanja kontaktnih napona u procesu sabijanja prizmatičnog pripremka od Čl1431 su izvedena su u Laboratoriji za tehnologije plastičnog deformisanja na Fakultetu tehničkih nauka u Novom Sadu. Provera tačnosti prikazane metode izvršena je na osnovu dijagrama deformacione sile određene direktnim merenjem tokom sabijanja $i$ integracijom eksperimentalno određenih kontaktnih napona. Metoda merne čivije omogućuje precizno određivanje kontaktnih napona u procesima plastičnog deformisanja, uz uslov da postoji mogućnost ugradnje mernih elemenata u radne elemente alata.
\end{abstract}

Ključne reči: Kontaktni naponi, Koeficijent trenja, Merna čivija, Cilindrični alati, Prizmatični pripremak 